
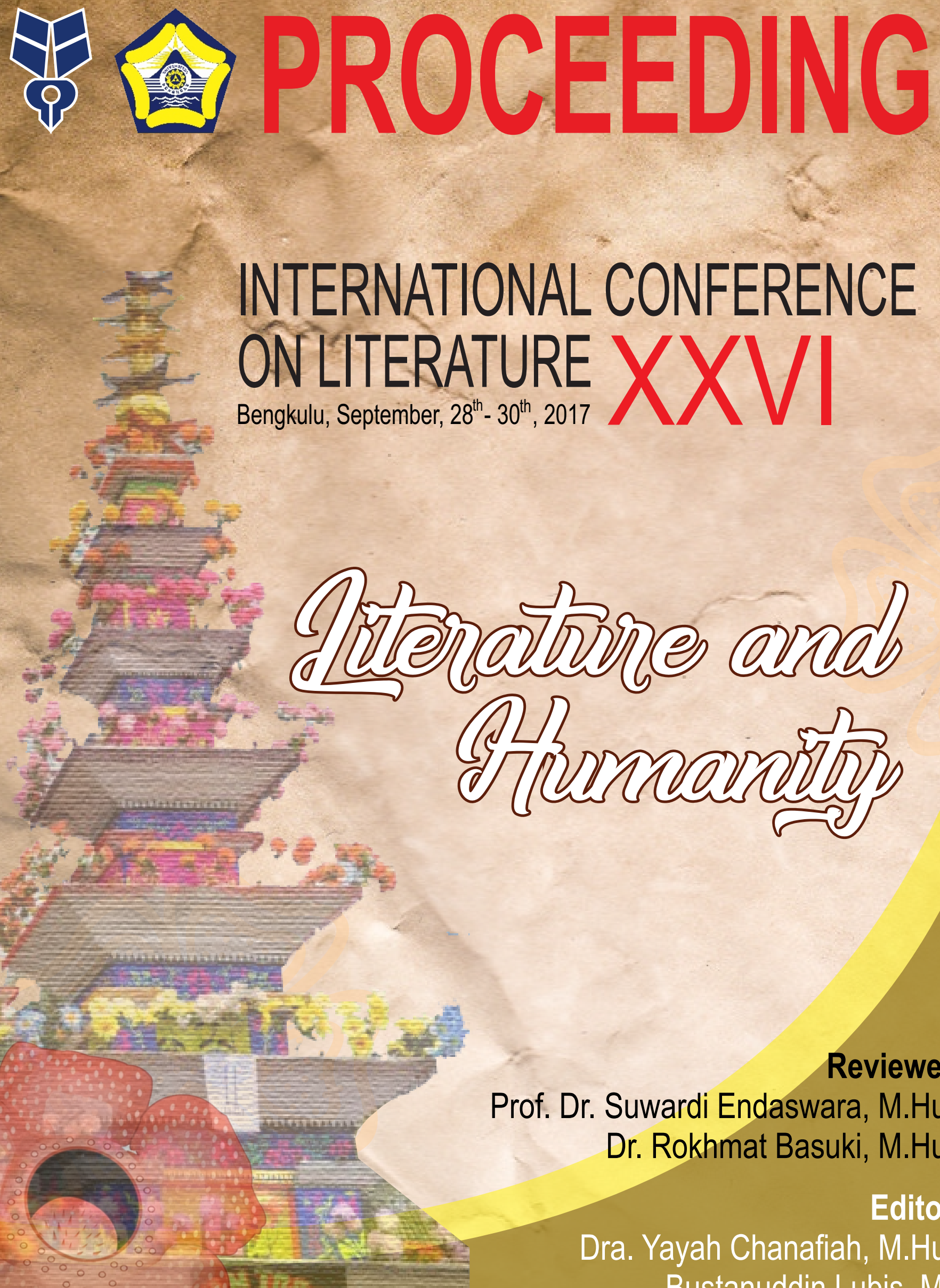

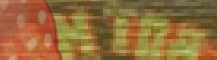

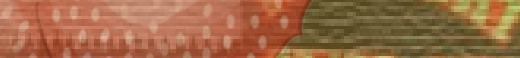

Reviewers:

Prof. Dr. Suwardi Endaswara, M.Hum. Dr. Rokhmat Basuki, M.Hum.

Editors:

Dra. Yayah Chanafiah, M.Hum. Bustanuddin Lubis, M.A.

HIMPUNAN SARJANA KESUSASTRAAN INDONESIA (HISKI) KOMISARIAT BENGKULU 


\title{
PROCEEDING
}

\section{INTERNATIONAL CONFERENCE ON LITERATURE XXVI}

Bengkulu, September, $28^{\text {th }}-30^{\text {th }}, 2017$

QPiterature and Hamanity

\author{
Reviewers: \\ Prof. Dr. Suwardi Endaswara, M.Hum. \\ Dr. Rokhmat Basuki, M.Hum.
}

Editors:

Dra. Yayah Chanafiah, M.Hum.

Bustanuddin Lubis, M.A. 


\section{PROCEEDING}

INTERNATIONAL CONFERENCE

ON LITERATURE XXVI

Bengkulu, September, $28^{\text {th }}-30^{\text {th }}, 2017$

\section{Qiterature and SFlamanity}

Reviewers:

Prof. Dr. Suwardi Endaswara, M.Hum.

Dr. Rokhmat Basuki, M.Hum.

Editors:

Dra. Yayah Chanafiah, M.Hum.

Bustanuddin Lubis, M.A.

Layout : Bustanuddin Lubis

Desain Cover : Denis Kurniawan, S.Pd.

(C) 2018

Hak cipta dilindungi undang-undang.

Dilarang memperbanyak atau memindahkan sebagian atau seluruh isi buku ini dalam bentuk apapun, baik secara elektrinis maupun mekanis, termasuk memfotokopi, merekam, atau dengan sistem penyimpanan lainnya, tanpa izin tertulis dari Penulis

HISKI KOMISARIAT BENGKULU

HISKI PUSAT

UNIVERSITAS BENGKULU

\section{Diterbitkan:}

Unit Penerbitan dan Publikasi FKIP UNIB

Gedung FKIP Universitas Bengkulu

Jln. WR Supratman Kandang Limun Bengkulu

Perpustakaan Nasional RI: Katalog dalam Terbitan (KDT)

PROCEEDING INTERNATIONAL CONFERENCE ON LITERATURE XXVI

Unit Penerbitan dan Publikasi FKIP UNIB, 2018

xxv, $937 \mathrm{hlm}$. ; 21 x 29,7 cm

ISBN 978-602-8043-94-6 


\section{SAMBUTAN KETUA HISKI KOMISARIAT BENGKULU}

Dengan menengadahkan kedua tangan, kami memanjatkan puji syukur ke hadirat Allah SWT, Tuhan Yang Maha Esa, yang telah memberi kekuatan, kesehatan, kesempatan kepada kami sehingga prosiding Konferensi Internasional Kesusasteraan Himpunan Sarjana Kesusasteraan Indonesia (Hiski) yang ke XXVI di Bengkulu dapat tersusun dan diterbitkan. Prosiding ini merupakan kumpulan makalah dan rekaman kegiatan selama berlangsungnya KIK Hiski, yang telah dilaksanakan tanggal 27-28 September 2017.

Tema yang diangkat dalam konferensi ini adalah "Sastra dan Humanitas". Konferensi ini dihadiri tigs pemakalah kunci yang sangat menguasai di bidangnya masing-masing, yaitu: Prof. Dr. Gufran Ali Ibrahim, M.S. (dari Badan Pengembangan dan Pembinaan Bahasa, Kementerian Pendidikan dan Kebudayaan), Christoper Allen Woodrich, M.A. (International Indonesia Forum - UGM), dan Prof. Dr. Suwardi Endraswara, M.Hum. (UNY). Di samping itu, terdapat juga sejumlah 140-an pemakalah pendamping, berasal dari berbagai perguruan tinggi di seluruh wilayah nusantara, yang dikategorikan dalam 3 (tiga) kelompok bidang kajian (Sastra, Linguistik, dan Pengajaran).

Hasil pemikiran dan kajian yang disajikan pada KIK Hiski XXVI ini selain diterbitkan dalam bentuk prosising cetak, juga diunggah secara online. Dengan demikian, diharapkan kajian akademis dan sumbangan pemikiran dari pakar-pakar kesusasteraan ini dapat diakses dan menjadi rujukan bagi pengembangan ilmu kesusasteraan di masa-masa mendatang.

Penghargaan dan apresiasi yang tinggi kami sampaikan kepada para pemakalah kunci yang telah berkenan hadir dalam konferensi ini. Terima kasih kami sampaikan kepada Ketua Hiski Komisariat Pusat yang telah membantu di dalam penyelenggaraan KIK Hiski di Bengkulu ini. Demikian juga kepada Kantor Bahasa Bengkulu, yang telah berkenan untuk menjalin kerja sama demi menyukseskan KIK Hiski ke XXVI ini. Dan tak kalah pentingnya, pengahargaan dan apresiasi yang serupa kami sampaikan kepada seluruh pemakalah pendamping yang telah berkenan menunangkan ide-ide, pemikiran yang inovatif, dan pencerahan tentang banyak hal dalam sesi diskusi paralel. Juga peserta konferensi yang telah hadir menyampaikan berbagai masukan ataupun pertanyaan sehingga suasana ilmiah dalam konferensi ini sangat kondusif dan menarik.

Akhir kata, mewakili seluruh panitia, kami mengucapkan terima kasih kepada semua pihak, khususnya Rektor Universitas Bengkulu, Dekan FKIP Universitas Bengkulu, Hiski Komisariat Pusat, Kantor Bahasa Bengkulu, Ketua Jurusan Pendidikan Bahasa dan Seni, Ketua Program Studi Pendidikan Bahasa dan Sastra Indonesia, serta semua pihak yang telah berperan aktif demi suksesnya penyelenggaraan Konferensi Internasional Kesusasteraan Hiski XXVI tahun 2017.

Permohonan maaf juga kami sampaikan kepada semua pihak atas kekurangan dan ketdakmaksimalan dalam penyelenggaraan konferensi, termasuk dalam pelayanan kepada seluruh peserta KIK selama berada di Bumi Raflesia. Juga dalam 'keterlambatan hadirnya 'prosiding' KIK ini. Tidak ada gading yang tak retak. Semua kembali karena ketidaksempurnaan kami sebagai manusia. Dan kepada Alloh kami mohon ampun. Semoga ketidaksempurnaan ini dapat disempurnakan di pertemuan yang akan datang. Semoga. Terimakasih.

Teriring salam HISKI... JAYA BERKARYA.

Bengkulu, September 2018

Ketua Komisariat Hiski Bengkulu,

Dr. Rokhmat Basuki, M.Hum. 


\section{Menarik nafas \\ Pengantar Prosiding}

Menarik nafas, lega. Begitu kesan awal dengan penerbitan prosidding ini. Tanggal 26 Jauari 2018, bu Yayah mengkontak saya untuk menuliskan ini. Sungguh sangat membanggakan, melegakan, dan sekaligus harus acung jempol. Kerja keras teman-teman HISKI komisariat Bengkulu, biarpun tidak banyak komen di grup WAG HISKI Pusat, namun tetap komit berproses. Ini sungguh pantas kita hargai.

Menarik nafas, dalam, sebab penerbitan prosiding Konferensi Internasional Kesusasteraan (KIK) yang ke-XXVI sudah terwujud dengan bagus. HISKI Pusat dan HISKI Komisariat Bengkulu sudah berupaya seoptimal mungkin untuk memenuhi persyaratan penerbitan prosiding, sesuai dengan tuntutan garansi keilmiahan. Atas nama HISKI Pusat tentu kami harus mengucapkan terima kasih yang tidak terhingga dengan terbitnya prosiding ini. Beberapa pihak yang pantas saya sebutkan adalah (1) kepada HISKI Komisariat Bengkulu yang telah menyelenggarakan KIK dengan sukses dan penuh tannggung jawab, (2) kepada program studi Pendidikan Bahasa dan Sastra Indonesia FKIP Universitas Bengkulu, yang telah memberikan sumbangan pemikiran dan dana, (3) kepada seluruh anggota HISKI yang ikut hadir menyumbangkan pemikiran.

Secara pribadi, saya jadi ingat ketika pembukaan KIK XXVI di lantai atas Rektorat Bengkulu. Dijemput dari berbagai hotel, teman-teman turun bus, langsung ber-selfi, sambil menuju ruang pertemuan. Saat itu, saya harus menarik nafas panjang, sebab kondisi badan sedang kurang fit. Saya seharian, sebenarnya ingin tiduran. Namun, dengan semangat teman-teman yang luar biasa, kondisi tubuh saya yang agak menurun tiba-tiba bangkit. Itulah sebabnya, pantas saya secara pribadi harus bersyukur dengan terselenggaranya KIK di Bengkulu, yang telah kami dahului dengan audiensi dengan Bapak Rektor, diterima dengan sangat bagus. Terima kasih bapak Rektor, Bapak Dekan FKIP, dan bapak Kepala Kantor Bahasa Bengkulu, yang waktu itu bersama-sama HISKI Komisariat Bengkulu bercanda ria membicarakan KIK, baru pertama kali tentang sastra bertaraf internasional.

Dengan menarik nafas, bangga, atas nama HISKI Pusat, sangat bersyukur dengan terbitnya prosiding yang lengkap ini. Semoga berbagai pihak yang terkait dan membutuhkan dapat memanfaatkan prosiding ini dengan baik. Dengan tema besar "Sastra dan Humanitas", prosiding KIK ini mewadahi seluruh pemikiran teman-teman HISKI. Dari sini pula saya memandang bahwa sastra itu memang memiliki keterkaitan langsung dan tidak langsung dengan humanitas. Sastra dapat mengangkat derajat humanitas setiap manusia. Melalui prosiding ini para pembaca dapat berkaca diri.

Sejenak,menarik nafas, segar. Harus kami sampaikan bahwa penerbitan prosiding hasil konferensi di Universitas Bengkulu dan hotel Grage Horison Bengkulu tanggal 28-30 September 2017, bukan saja sebuah dokumen keilmuan sastra,namun juga mewujudkan kerja keras panitia dan HISKI komisariat Bengkulu yang sangat luar biasa. Semoga penerbitan prosiding ini dapat dimanfaatkan oleh teman-teman, memberikan inspirasi untuk penerbitan KIK ke-XXVII yang akan diselenggarakan di Bangka Belitung, tanggal 20-23 September 2018. Prosiding ini tentu telah melalui proses panjang, melalui seleksi, editing, dan ketelitian berbagai pihak.

HISKI Pusat merasa bangga dengan penerbitan prosiding ini. Sebab, dokumentasi ilmiah akan terdokumentasi secara profesionaal dan rapi. Selain itu, HISKI juga mengucapkan terima kasih yang sangat luar biasa kepada para tim editor, tim penyeleksi, dan segenap pihak yang tidak dapat kami sebutkan satu per satu atas kerjasamanya. Semoga amal baik teman-teman, mendapat imbalan dari Allah SWT. Dengan semboyaan dan salam emas HISKI "Jaya berkarya", menandai bahwa kreativitas, kejelian, keilmiahan, dan tanggung jawab teman-teman berolah sastra ada dalam prosiding ini.

Akhirnya, kami harus menarik nafas, sukses, hingga berharap semoga prosiding ini memenuhi harapan semua pihak, lebih bermanfaat. Setidaknya bagi pengembangan sastra yang sampai akhir-akhir ini tengah ingin meninggalkan kemodernan menuju "post theory". Serpihan pemikiran dalam prosiding ini merupakan potret sastra masa kini. Sastra yang penuh liku-liku dan kebermanfaatan bagi humanitas. Selamat membaca. Kritik dan saran tentu selalu kami harapkan, baik secara lisan maupun tertulis demi kesuksesan bersama.

Yogyakarta, 26 Januari 2018

Ketua Umum HISKI Pusat

Prof. Dr. Suwardi Endraswara, M.Hum. 


\section{SAMBUTAN REKTOR UNIVERSITAS BENGKULU}

Assalamualaikum warahmatullah wabarakatuh

Selamat pagi, dan salam sejahtera untuk kita semua.

Selamat Datang di Universitas Bengkulu

Yth. Kepala Badan Pengembangan dan Pembinaan Bahasa, Kementerian Pendidikan dan Kebudayaan

Yth. Dekan FKIP Univeresitas Bengkulu

Yth. Kepala Kantor Bahasa Bengkulu

Yth. Ketua Komisariat Pusat Himpunan Sarjana Kesusastraan Indonesia (Hiski)

Yth. Para Pemakalah dari berbagai daerah di tanah air dan juga dari luar Indonesia, yang dapat hadir pada

kegiatan ini

Yth. Seluruh peserta Konferensi Internasional Kesusastraan Hiski ke-XXVI yang berbahagia.

Mengawali sambutan ini, marilah kita panjatkan puji syukur ke hadirat Allah SWT., yang telah memberi kesehatan dan kesempatan kepada kita untuk bertemu, bersilaturahmi, dan bertukar pikiran tentang berbagai perkembangan bidang sastra, bahasa dan pembelajarannya, di Ruang Rapat Utama Gedung Rektorat Universitas Bengkulu.

Pada kesempatan ini, perkenankan kami menyampaikan ungkapan perasaan bangga, hormat, dan tersanjung, atas kepercayaan yang diberikan kepada Universitas Bengkulu, untuk menyelenggarakan kegiatan Konferensi Internasional Kesusastraan (KIK) Himpunan Sarjana Kesusastraan Indonesia (Hiski) yang ke- XXVI. Konferensi ilmiah ini diadakan melalui kerjasama Hiski Komisariat Daerah Bengkulu, FKIP Universitas Bengkulu, maupun dengan Jurusan Pendidikan Bahasa dan Seni FKIP Universitas Bengkulu.

Ucapan terimakasih kami sampaikan kepada seluruh peserta KIK Hiski yang berkenan untuk datang ke Bengkulu, khususnya ke Universitas Bengkulu untuk ikut berpartsipasi dan bertukar pikiran tentang perkembangan bahasa, sastra dan pembelajarannya.

Suatu bangsa terbentuk apabila dalam kelompok manusia itu terdapat nilai-nilai yang sama dan keinginan yang kuat untuk hidup bersama. Nilai-nilai yang sama ini dapat benar-benar sama, dapat berakar dari suatu kebudayaan yang lebih kurang sama, dan dapat pula berupa aspirasi untuk bersatu, dengan dilandasi kesadaran atas suatu realitas bahwa dalam kesamaan dan kebersamaan pada hakikatnya terdapat berbagai perbedaan. Menyadari hal ini, bangsa Indonesia merumuskan dalam semboyan bhineka tunggal ika, yang bermakna meskipun berbeda-beda tetapi ada keinginan untuk tetap menjadi satu.

Realitas historis menunjukkan bahwa bangsa Indonesia berdiri tegak di antara keragaman budaya. Salah satu contoh nyata dari hal itu adalah dipilihnya Bahasa Melayu sebagai akar bahasa persatuan yang kemudian berkembang menjadi Bahasa Indonesia. Sebagai bangsa yang majemuk dan heterogen, Bangsa Indonesia memiliki keunggulan dibandingkan negara lain, yakni penetapan Bahasa Indonesia sebagai bahasa nasional. Kita patut bangga sebagai Bangsa Indonesia karena telah memiliki bahasa nasional jauh-jauh hari sebelum bangsa ini merdeka.

Sementara itu, melalui karya sastra, kita dapat belajar mengenal dan memahami keragaman budaya di Indonesia. Ini lantaran karya sastra juga menyediakan informasi keragaman budaya yang melatari kelahirannya. Keluasan dan kedalaman segala hal yang terkandung dalam karya sastra mengindikasikan pengakuan tentang keragaman, baik berupa keragaman pandangan hidup, sikap, pola pikir, serta keragaman pokok persoalan yang ditampilkan dalam karya-karya sastra.

Selanjutnya, seiring dengan pesatnya perkembangan dan kemajuan teknologi informasi secara global, untuk pengajaran bahasa dan sastra tentu juga perlu dibahas dalam seminar ini.

Dan pada akhirnya, dengan mengucapkan bismillahirrahmanirrahim, Konferensi Internasional Kesusastraan Hiski ke- XXVI, dengan tema Sastra dan Humanitas secara resmi dibuka.

Selamat berseminar, berkonferensi. Semoga dihasilkan rumusan-rumusan yang sangat bermanfaat bagi perkembangan bahasa dan sastra Indonesia di masa mendatang. Terima kasih.

Wassalamualaikum warahmatullahi wabarakatuh.

Rektor Universitas Bengkulu

Dr. Ridwan Nurazi, M, Sc. 


\section{KATA PENGANTAR}

Dengan mengucapkan syukur alhamdulillah, pada akhirnya Prosiding Konferensi Internasional Kesusastraan (KIK) Himpunan Sarjana Kesusastraan Indonesia (Hiski) yang ke-XXVI di Universitas Bengkulu dapat tersusun dan tercetak. Finalisasi yang panjang dalam proses editing dan serta proses pengurusan ISBN yang juga bermasalah akhirnya penyelesaian prosiding KIK Hiski ke-XXVI dapat selesai berkat dukungan yang penuh dari berbagai pihak, terutama dari Ketua Hiski Komisariat Pusat, beserta rekanrekan panitia, yang telah banyak memberikan masukan dan support yang sangat bermanfaat dalam penyusunan prodising ini.

Tentunya prosiding ini masih ada ketidaksempurnaan, ada kekurangan dan kelemahan, baik pengetikan, layout, penyusunan artikel-artikelnya. Oleh karenanya, kami dengan senang hati dan tangan terbuka menerima saran dan masukan untuk perbaikan.

Permohonan maaf juga kami sampaikan kepada semua pihak atas kekurangan dan ketdakmaksimalan dalam penyelenggaraan konferensi, termasuk dalam pelayanan kepada seluruh peserta KIK selama berada di Bumi Raflesia. Juga dalam 'keterlambatan hadirnya 'prosiding' KIK ini. Ini menjadi pekerjaan berat kami ditengah kesibukan instansi dan tuntutan pekerjaan yang lainnya. Kami berlajar dari peristiwa ini semua. Tidak ada gading yang tak retak. Semua kembali karena ketidaksempurnaan kami sebagai manusia dan kepada Allah SWT kami mohon ampun.

Akhir kata, sekali lagi kepada semua pihak yang tidak kami sebut satu persatu yang telah memberikan sumbangan, baik tenaga maupun pikiran dalam proses penyusunan prosiding ini diucapkan terima kasih. Semoga Allah SWT menjadikan ini sebagai kebaikan dan amal kita. Amin.

Teriring salam.

Bengkulu, September 2018

Panitia 


\section{DAFTAR ISI}

Sambutan Ketua Hiski Bengkulu ........................................................................................

Sambutan Ketua Umum Hiski .......................................................................................... iv

Sambutan Rektor Universitas Bengkulu ................................................................................. v

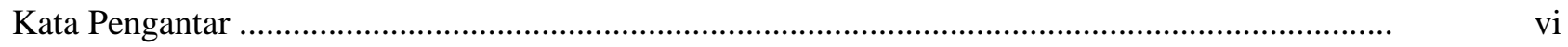

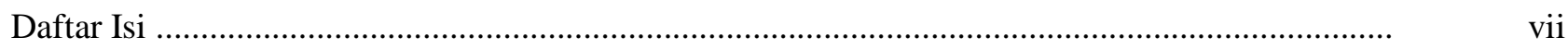

Jadwal KIK Hiski XXVI .......................................................................................... xvi

\section{MAKALAH UTAMA}

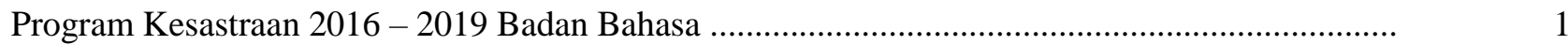

Gufran A. Ibrahim

A History Of The Advertising Of Filmic Adaptations Of Novels In Indonesia (1927-2017) .

Christopher A. Woodrich

Dehumanisasi Sastra

Suwardi Endraswara

\section{MAKALAH PENDAMPING BIDANG SASTRA}

Local Wisdom dalam Sastra Indonesia

Harapan yang Luruh Selagi Tumbuh: Perempuan dan Kehidupan Pernikahan dalam Beberapa Cerpen Terpilih Karya Catherine Lim

Literature And Power: The Study Of Javanese Traditional Historiographical Texts Of The $12^{\text {th }}$ $17^{\text {th }}$ Century

Anung Tedjowirawan

Disclosure, Justice, and Humanity In Coastal Stories

Prof. Dr. Agus Nuryatin, M.Hum. dan Mulyono, M.Hum.

Peranan Organisasi Komunitas Sastra untuk Merevitalisasi Kearifan Lokal dalam Sastra

Prof. Dr. Ida Bagus Putera Manuaba, M.Hum.

Ketika Bumi Menaklukkan Langit: Kajian Naratologi Kana Inai Abang Nguak dalam Perspektif A. J. Greimas

Sri Astuti dan Yoseph Yapi Taum

Sastra dalam Politik Identitas Masyarakat Sasak

Dr. I Made Suyasa, M.Hum.

The Conception Of Divinity Among Ngaju The Adherent Of Kaharingan In Central Kalimantan Based On Sacred Tales 
Flouting Conversational Maxim In Bernard Shaw's "Pygmalion"

Membaca Nilai Kemanusiaan dalam Novel Autobiografi Indonesia

Suminto A. Sayuti, Wiyatmi, dan Dwi Budiyanto

Estetika Sastra Tradisi ( Hikayat Deli) Pelerai Konflik Etnik di Tanah Deli

Prof. Wan Syaifuddin, M.A., Ph.D.

Perempuan, Strategi, dan Ambivalensi dalam Karya Drama Peranakan Tionghoa

Dr. Cahyaningrum Dewojati, S.S., M.Hum.

Between The Greed Of Commodity and Desacralization Of Passiliran Tradition In The Short Story Of "Di Tubuh Tarra, dalam Rahim Pohon" By Faisal Oddang ..... Ahmad Junaidi

Aspek Humanisme dalam Kumpulan Cerpen Harga Perempuan Karya Sirikit Syah

Siti Ajar Ismiyati, S.Pd., M.A.

Sisi-Sisi Kemanusiaan Doben Karya Maria Matildis Banda

Dr. Drs. I Ketut Sudewa, M.Hum

Modal Budaya dan Modal Sosial dalam Sastra Lisan Bhanti-Bhanti Wakatobi: Analisis Pierre

Bourdieu

Sumiman Udu

Local Wisdom and Cross Cultural Communication In Education Context

Dr. Fatmah AR. Umar, M. Pd.

Naipaul's The Enigma of Arrival In Viewing The Past Due To The Context Of Human

Civilization

Gabriel Fajar Sasmita Aji

Nyanyian Tradisional Kagombe Untuk Menyembuhkan Penyakit Cacar Pada Masyarakat Muna.

Hadirman dan Ardianto Kusnan

Anekdot Tentang Kekuasaan dan Mentalitas dalam Cerkak "Kursi" dan "Ledhek" Karya Krishna Miharja

Yohanes Adhi Satiyoko

Ekokritik dan Ekofeminisme Sebagai Jalan Memperkokoh Harmonisasi Manusia dengan Lingkungan

Wiyatmi

Pendidikan dan Nasionalisme: Menakar Nilai-Nilai Kebhinekaan dalam Buku Ajar Sekolah Dasar di Kota Depok

Dr. Christina Suprihatin

Pandangan Hidup Tokoh Perempuan dalam Novel-Novel Karya Abidah El Khalieqy (Suatu Kajian Feminisme)

Dra. Yenny Puspita, M.Pd.

Nilai Budaya dalam Cerita Rakyat "Bau Harum Malam Kamis" dari Dayak Benuaq, Kalimantan 
Kearifan Lokal dalam Sastra Lisan di Sulawesi Tengah

Dr. Yunidar Nur, M.Hum.

A Suffered-From Cancer Girl's Values Portrayed In "A Letter For God” (Written By Gita Sesa Wanda Cantika)

Yusuf Al Arief

Absurdisme Khas Indonesia dalam Naskah Drama Kapai-Kapai Karya Arifin C Noer

Turahmat, Agus Nuryatin, Suminto A.Sayuti, dan Teguh Supriyanto

Warna Lokal Batak Toba dalam Novel Mangalua Karya Idris Pasaribu (Kajian Antropologi Sastra)

Jafar Lantowa, S.Pd.,M.A. dan Zilfa A. Bagtayan, S.Pd.,M.A.

Identitas dalam Novel Maryam Karya Okky Madasari

Eka Ugi Sutikno dan Ahmad Supena

Harmoni Sosial dalam Novel-Novel Karya Tere Liye

Rianna Wati

Menguak Makna Tak Terkatakan: Sebuah Upaya Pemaknaan Simbol Kekuasaan dalam Iluminasi Manuskrip Jawa Serta Relevansinya Dengan Pendidikan Karakter

Venny Indria Ekowati, Sri Hertanti Wulan, dan Aran Handoko

Legenda Mitos dan Maknanya dalam Batik Jambi

Dr. H. Supana, M.Hum dan Prof. Dr. Bani Sudardi, M.Hum

Fiksi dan Fantasi dalam Animal Medicine Jawa

Drs. Wiranta, MS, Dra. Murtini, MS, dan Prof. Dr. Bani Sudardi, M.Hum.

Represi dalam Ekspresi: Wajah Kekerasan di Tanah Papua dalam Antologi Cerpen Aku Peluru Ketujuh Karya Topilus B. Tebai

Suma Riella Rusdiar

Humanitas dalam Dinamika Lintas Budaya: Representasi Relasi Antaretnik di Bali dalam Novel Indonesia

I Made Sujaya

Analisis Psikologis Tokoh Utama Novel Cinta Suci Zahrana Karya Habiburrahman El Shirazy.

Ira Yuniati, $M . P d$.

The Humanity Value In Oral Literature Of Serawai

Irma Diani

Reading Six Narrations Of The Psychosexual Development Of Disabled Character In R.J. Palacio's Wonder

Eva Leiliyanti dan Rahmat Alwi

Pengembangan Naskah Drama Berbasis Cerita Rakyat untuk Peningkatan Kemampuan Mahasiswa Pada Mata Kuliah Pementasan Drama 
Sastra Sebagai Inspirasi Motif Batik

Prof. Dr. Bani Sudardi, M.Hum.

Pewarisan Guritan Sebagai Model Pelestarian Tradisi Lisan Nusantara

Dr. Suhardi Mukmin, M.Hum.

Dehumanisasi dalam Konteks Sastra Kontemporer

Dr. Hendratno, M.Hum.

Estetika Bunyi pada Kumpulan Puisi Anak-Anak Andai Aku Jadi Presiden Karya Neva

Zahrani.

Masfu'ad Edy Santoso, Sri Mulyati, dan Tri Mulyono

Iktibar Keberanian Menyelamatkan Dunia dalam Novel The Lost Hero Karya Rick Riordan (Kajian Sosiologi Sastra)

Effrina Yurick

Cultural Violence Represented In Indonesian and American Literatures

Fatchul Mu'in

Berbalas Pantun di Sawah: Tradisi Lisan di Nagari Tabek, Sumatra Barat Sebagai Ajang Pembebasan dari Pergunjingan

Krisnawati, M. Hum.

Ideologi Patriarki dalam Novel Perempuan Berkalung Sorban Melalui Perspektif Gender dan Feminisme

Maria Botifar, M.Pd.

Use The Karungut As Means To Grow The Pancasila Values

Basori

The Radical Ideology In Poem "Nggahi Dana" In Society's Game In Dompu Regency: Hermeneutic Study

Wawan Irawan dan Irwansyah

Relevansi Naskah Hikayat Kalilah dan Dimnah dalam Pola Kehidupan Bermasyarakat

Teguh Prakoso dan Venus Khasanah

Local Colour As A Breaking The Shackles Of Post Colonialism and Its Hegemony Practices In The Modern Indonesian Literature

Teguh Supriyanto

Statelessness and Unhomeliness In Nh. Dini's Pada Sebuah Kapal, La Grande Borne and Dari Fontenay Ke Magallianes: Issues In Transnational Marriage

Ali Mustofa

Radikalistis Anak dalam Novel Karya Anak Indonesia

Prof. Dr. Suyatno, M.Pd.

Babad Ngayogyakarta HB IV-V A Picture Of Multiculturalism

Arsanti Wulandari, S.S, M.Hum.

Nilai-Nilai Kemanusian dalam Sastra Lokal 
Sisi Positif dan Sisi Negatif Ki Ageng Pemanahan pada Cerita-Cerita Legenda dalam Antologi Cerita Rakyat Daerah Istimewa Yogyakarta

Septina Krismawati, S.S., M.A.

Sastra Sebagai Mediasi “Tekstual” Kemanusiaan

Sugiarti

Karakter Multitokoh dalam Cerita Rakyat Multikultur di Provinsi Sulawesi Tengah

Dr. Sugit Zulianto, M.Pd.

Merantau: Catatan Perjuangan Seorang Aku Mempertahankan Hidup dalam Cerpen Wanita

Pemecah Batu Karya Marlin Lering

Alexander Bala, S.Pd., M.Pd.

An Analysis Of A Novel 99 Cahaya di Atas Langit Eropa By Hanum Salsabiela and Rangga Almahendra By Using A Theory Of Hermeneutic Dilthey

Sari Wahyuni, Susetyo, dan Sarwit Sarwono

Dari 'Diaspora Sastra' Sampai Tema Kemanusiaan di dalam Antologi Puisi

Jabrohim

Gambaran Tentang Orang-Orang Tionghoa Peranakan dalam Karya Sastra yang Terbit dalam Seri Majalah Penghidoepan Tahun 1925-1928 di Surabaya

Adi Setijowati

Kehidupan Sosial Tokoh dalam Novel Oeroeg Karya Hella S. Haasa

Sance A Lamusu

Paradoks Lelaki dalam Cerpen Laki-Laki Sejati Karya Putu Wijaya dari Tinjauan Feminisme

Jiko Vindhy Mega Wianto

Bahasa dan Sastra Daerah untuk Memperkokoh Budaya Bangsa

Nanik Herawati

Balinese Folksong As A Work Of Traditional Value Enculturation In Modern Context

Ni Wayan Sumitri

Refleksi Kegetiran Sosial dalam Cerpen "Pegawai Negeri Sipil“" Karya Dien Wijayatiningrum.... Ninawati Syahrul

Fenomena Perkembangan Karya Fiksi dalam Tanggapan Media Massa Indonesia Selama 2016

Nurhadi BW, Kusmarwanti, dan Dian Swandayani

Sastra Sebagai Alat Perjuangan untuk Menegakkan Nilai Humanisme: Studi Kasus pada Beberapa Tokoh Kaum Quaker Amerika Sebelum Abad Ke-20

Nuriadi

Elaborasi Citra Perempuan Islam dalam Karya Sastra dalam Rangka Memperkuat Karakter Anak Bangsa.

Rina Listia

Mutual Respect (Sipakalabbirik), Mutual Warning (Sipakaingak), and Human Respect Each Other (Sipakatau) In Oral Literature "Didek" At Kepulauan Selayar 
Kerudung Santet Gandrung dan Niti Negari Bala Abangan Dialektika Sastra dan Tradisi SubKultur Masyarakat Using-Banyuwangi .....

Novi Anoegrajekti

Representasi Keberagaman Masyarakat Belitung dalam Novel Karya Andrea Hirata (Kajian Strukturalisme Genetik)

Siti Rukiyah

Pemertahanan Taenango Sebagai Sastra Lisan Tolaki: Mengulik Sisi Humanitas Masyarakat Tolaki

Uniawati

Sahibul Hikayat: Revitalisasi, Hibriditas dan Identitas Betawi di Perkampungan Setu Babakan.... Siti Gomo Attas

Komitmen Beragama Tokoh dalam Cerpen Robohnya Surau Kami

Munaris dan Fisnia Pratami

Imagery Of Religious Humanism Syiir North Coastal Of Central Java

Muhamad Burhanudin, M.A.dand Prof. Dr. Agus Nuryatin, M.Hum.

Kontroversal Pemikiran H.B. Jassin dengan Para Sastrawan (Sebuah Analisis melalui Surat-Surat H.B. Jassin)

Dr. Mulyanto Widodo, M.Pd.

Mantra Pengasihan dalam Aspek Mikro dan Makro

Yanti Sariasih

Fungsi Sosial-Kultural Sastra: Memajukan Kebudayaan dan Mengembangkan Peradaban

Redyanto Noor

Peran Gender dalam Cerita Pendek Между Небом И Землей/Antara Langit dan Bumi Karya Viktoriya Samoilovna Tokareva

Thera Widyastuti

Humanisme dan Liberalisme dalam Cerita Rakyat Sebagai Strategi Penguatan Nilai Karakter Berbasis

Kearifan Lokal ....

U'um Qomariyah, S. Pd., M. Hum.

Nilai-Nilai Kemanusian di dalam Karya Sastra Lama

Yayah Chanafiah

Leningo, Sastra Humanitas dari Gorontalo: Konkretisasi Nilai-Nilai

Dr. Herman Didipu, M.Pd.

Menulis Kreatif Cerita Rakyat Minangkabau Sebagai Modal Pembentuk Karakter Bangsa

Dr. Silvia Rosa, M. Hum.

Leksia-Leksia In Poems "Potong Bebek Angsa" The Work Of Hamid Jabbar

Fina Hiasa

Education Values That Using In The Novel Cinta Suci Zahrana By Habiburrahman El Shirazy .... Asri Dyarti dan Susetyo

Perulangan Pola Geometri Suci Sebagai Representasi Ekologis dalam Supernova: Akar 


\section{MAKALAH PENDAMPING BIDANG LINGUISTIK}

Kekhasan Gelar Sapaan Bahasa Gorontalo

Kajian Etnosemantik: Kesepadanan Makna Peribahasa Bersumber Nama Binatang dalam Bahasa

Fenomena Ragam Bahasa Jawa Dialek Tengger: Potret Pementasan Sendratasik Kusuma Yajña Garapan Komunitas Gatra UM

Teguh Tri Wahyudi, S.S. M.A.

Language Preservation Through Kinship Investigation Between Gorontalo Language With Suwawa Language In Province Of Gorontalo

Dr. Asna Ntelu, M.Hum dan Dr. Dakia N. Djou, M.Hum.

Semiotics On The Tombstone King Of Prailiu Kelurahan Prailiu District Kambera East Sumba Regency

Citra Perempuan dalam Berita Pemerkosaan di Surat Kabar Malang Post Edisi 1 Juli - 11 Agustus 2017

Strengthening Indonesian Language Based An The Problem Of Diversity In Venaculer Vocabuleries 
Mensinergikan Cerita Dalam Alquran dengan Pembelajaran Bahasa dan Sastra Indonesia

Izzah Zen Syukri, S.Pd., M.Pd.

Retelling Story Through Strip Story

Erna Novalinda

Pengejawantahan Kode Budaya dan Kode Jurnalistik dalam Perspektif Hermeneutika pada Cerpen Orang-Orang dari Selatan Harus Mati Malam Itu Karya Faisal Oddang

Istiqbalul Fitriya dan Riko Hermanto

Preservation and Revitalization Of Palembang Malay Language Through Traditional Art Of

Dulmuluk

Emawati, M.Pd.

\section{MAKALAH PENDAMPING BIDANG PENGAJARAN}

Pembentukan Karakter Peserta Didik Melalui Sastra Anak Berbasis Lokal 'Nene Pakande'.........

Dr.Juanda, M.Hum.

Penanaman Nilai-Nilai Karakter dalam Pembelajaran Apresiasi Sastra di Sekolah

H. Mursalim

Pemanfaatan Budaya Lokal dalam Pembelajaran Bahasa Inggris

Dr. Cayandrawati Sutiono, M.A.

Pembentukan Karakter Siswa di Sekolah Melalui Pembelajaran Sastra

Nur Mei Ningsih, S.Pd.,M.Pd.

Nilai-Nilai Pendidikan Karakter Tokoh "Lahilote" Cerita Rakyat Gorontalo

Ellyana Hinta

Character Learning Using The Javanesee "Tembang Macapat” In Primary School

Heru Subrata

Meningkatkan Kepercayaan Siswa Terhadap Guru Melalui Pemodelan di SMAN 7 Bandarlampung ....

Dr. Yuli Yanti, M.Pd.

Analisis Tema Nasionalisme pada Tulisan Cerita Siswa Kelas X SMA Aji Kuning Kecamatan Sebatik Kabupaten Nunukan Propinsi Kalimantan Utara

Siti Fathonah dan Muhammad Thobroni

Pengembangan Lembar Kegiatan Siswa Pembelajaran Menulis Puisi Berbasis Nilai-Nilai Nasionalisme dalam Syair Lagu-Lagu Keroncong Ciptaan Ismail Marzuki untuk Siswa SMP

Kelas VII

Preni Reliyanti, M.Pd.

Tradisi Lisan Badampiang di Pesisir Selatan Sumatra Barat

Eva Krisna-Suprayogi

The Effect Of Peer Corrections To Grammatical Accuracy In Students' Essay Writing Apriana

Penguatan Pendidikan Karakter Peserta Didik Melalui Tokoh Utama dalam Novel Kooong Karya Iwan Simatupang 
Pembelajaran Sastra Berbasis Karakter Melalui Model Pembelajaran Cooperative Learning untuk Meningkatkan Kemampuan Menulis Drama

Dr. Sakdiah Wati, M.Pd.

The Use Of Tere Liye's Novels To Build The Students' Character In The Process Of Teaching and Learning

Dr. Noor Eka Chandra, M.Pd.

Alihwahana Karya Sastra Sebagai Sarana Penguatan Karakter Anak

Dr. Mukh Doyin, M.Si.

Revitalisasi Nilai-Nilai Kearifan Lokal Melalui Pembelajaran Sastra Daerah

Prof. Dr. Hj. Sayama Malabar, M.Pd

A Creative Teacher For Problematic Students: An Individual Psychological Study On Freedom Writers Movie

Dr. Abdillah Nugroho

Nilai Pendidikan Pada Lirik Lagu Lampung

Dr. Surastina, M.Hum.

Guru dan Pembelajaran Sastra Berbasis Karakter

Dr. Sri Widayati, M. Hum.

Pelaksanaan Pembelajaran Menulis Artikel Bagian Hasil Penelitian dan Pembahasan pada Mahasiswa Program Pascasarjana (S-2) Pendidikan Bahasa Indonesia FKIP UNIB

Sefta Kurniawan, M.Pd., Dr. Suhartono, M.Pd. dan Dr. Dian Eka Chandra W, M.Pd.

Peringatan dan Pelajaran dalam Karakter Manusia Berdasarkan Serat Pawukon

Endang Tri Irianingsih, S.S. dan Prof. Dr. Bani Sudardi, M.Hum.

Nilai-Nilai Pendidikan dalam Cerita Rakyat Bengkulu

Titih Nursugiharti, S.Pd.

Project-Based Drama Learning To Improve Students' Reading Achievement

Fiftinova dan Muslih Hambali

People-Based Literature-Based Literature Learning In Order To Cultivate Values-Nilai Character Education

Emi Agustina

Klausa Bahasa Lembak Kelingi

Supadi

Rumusan Pemaparan Bidang Sastra

Rumusan Pemaparan Bidang Linguistik

Rumusan Pemaparan Bidang Pengajaran 
NILAI-NILAI KEMANUSIAN DALAM SASTRA LOKAL

Dr. Muliadi, M. Hum.

Email:mul_sam@yahoo.co.id

\begin{abstract}
Literature as a creative work carries value according to the context of the times and the place where it was created. This shows that the literary work is inseparable from the socio-cultural influence of the writer. In other words, literature is not born in a cultural vacuum. The value of humanity targeted in this paper is the ethical value. The object of study is the local literature with the use of the hermeneutika Paul Ricoeur.
\end{abstract}

Key Words: Humanity and Local Literature

\title{
PENGANTAR
}

Sastra sebagai karya imajinatif merupakan hasil kreatif dari sang Penyair atau Sastrawan. Penyair dalam menorehkan imajinasinya tidak terlepas dari konteks nilai sosial budaya yang melatarinya. Hal ini pula yang disebut bahwa sastra lahir tidak terlepas dari kekosongan sosial budaya (istilah A. Teeuw). Sastra meliputi fiksi atau prosa (cerita, cerpen, cerber, novel), drama, dan puisi. Sastra yang tergolong cerita, penyebarannya terbagi dua, yaitu pertama melalui penuturan dari si pencerita kepada si pendengar secara turun temurun dalam lingkup keluarga atau kerabat. Cara ini dilakukan oleh nenek moyang kita pada zaman dahulu. Kedua melalui tulisan. Cara kedua ini dianggap lebih efektif dan efisien dalam penyebarannya karena dalam waktu singkat dapat tersebar ke berbagai penjuru wilayah, bahkan sampai ke dunia mancanegara dengan dukungan informasi teknologi (IT) yang canggih. Cara kedua ini pula sastra (cerita) lokal dapat kita lestarikan atau pertahankan dan sebarkan sampai ke anak cucu kita (generasi berikut).

Penggalian sastra lokal yang syarat dengan nilai-nilai kemanusiaan sangat tepat dilakukan pada era kini. Era kini merupakan era yang memuji-muji kekayaan yang bersifat bendawi dan menyepelekan atau mengenyampingkan kekayaan yang bersifat nonbendawi, seperti sifat kepedulian. Pada hal, kebahagian hidup tidak selamanya hanya bersumber dari banyaknya kekayaan yang bersifat bendawi. Tidak sedikit orang yang memiliki kekayaan bendawi yang melimpah, tetapi hidupnya tidak merasa tenang, bahkan berakhir dengan tragis, yaiłu meninggal dengan bunuh diri, seperti: 1) James Whale salah satu pengarah film tersohor di zamannya meninggal dunia karena bunuh diri dengan cara membentur-benturkan kepalanya di dasar kolam, pada tanggal 29 Mei 1957, kata terakhirnya adalah: "Masa depan hanya usia tua dan sakit dan nyeri ... aku harus memiliki kedamaian dan ini adalah satu-satunya cara." ; 2) George Eastman adalah pembuat film yang tersohor, meninggal dunia dengan cara bunuh diri, pada tanggal 14 Maret 1932 Kata terakhirnya adalah: "Untuk teman-temanku: pekerjaanku selesai. Mengapa menunggu?"; 3) Christine Chubbuk adalah penyiar TV Amerika Serikat, yang berita-beritanya selalu dinantikan oleh pendengamya, meninggal dunia pada tanggal 15 Jali 1974, kata terakhirnya adalah: "Dan sekarang, sesuai dengan kebijakan Channel 40's yang selalu membawa Anda berita terbaru dalam darah dan nyali, dalam hidup yang berwarna. Untuk pertama kalinya Anda akan melihat percobaan bunuh diri."

Nilai yang termuat dalam karya sastra (cerita) dapat bervariasi, seperti nilai religius, filosofis, nilai estetis, dan nilai etis. Namun, dalam tulisan ini nilai yang dibahas adalah nilai yang terkait dengan nilai etis
sosial.

Nilai memiliki kesamaaan makna dengan kata value dalam bahasa Inggris, valere dalam bahasa Latin, dan valoir dalam bahasa Prancis Kuno, yang disebut keberhargaan atau kebaikan (Mulyana, 2004:7). Nilai menjadi sesuatu yang fenomenal dan sangat khas dalam kehidupan manusia ketika dipandang dalam konteks tertentu. Fenomenal karena tidak semua orang sepakat untuk mendefinisikan nilai secara seragam dan sangat khas karena belum tentu semua orang memberikan penilaian yang sama terhadap suatu objek yang diamati. Contohnya, dua pemuda yang ditawari sebuah jam yang bagus. Kedua pemuda tersebut belum tentu menilainya sama, mungkin orang yang pertama menilainya bagus dan segera mau memilikinja, sedangkan orang yang kedua menilainya tidak bagus karena modelnya, sehingga tidak tertarik untuk
memilikinya. Iskandar (1998:864) menyatakan bahwa nilai merupakan derajat, kualitas, mutu, taraf, sifat
ketinggian pemikiran, agama, dan kemasyarakatan. Hal ini berarti nilai ialah sesuatu yang tinggi dan
berharga, penting dan sangat perlu bagi kehidupan manusul yang dipandang berharga oleh manusia atau kelompok manusia. Sementara, Ali ibn Abi Thalib (dalam alQarni, 2008: 178) menyatakan bahwa nilai manusia terdapat dalam perbuatan baik yang dia lakukan. 


\section{PROCEEDINGS INTERNATIONAL CONFERENCE ON LITERATURE XXVI}

Maknanya, ilmu pengetahuan manusia, adab kesopanannya, ibadah, kedermawanan, serta akhlak dan moralitasnya al-Baqarah:221) yang artinya, "Sesungguhnya budak yang mukmin lebih baik daripada orang depgan (QS. Alaupun dia menarik hatimu." muly ${ }^{\text {Ink }}$ Aturan etika tidak dapat dipisahkan dari kehidupan manusia karena dinilai sebagai tata cara yang mengatur kehidupan manusia. Plato mengatakan bahwa etika adalah ilmu yang mengajarkan manusia bagaimana manusia itu bijaksana (dalam Amir, 1986:97). Dalam perspektif filsafat, etika termasuk dalam salah satu bidang nilai sehingga disebut nilai etika atau nilai etis. Nilai etis berkaitan dengan prinsip-prinsip moral yang seharusnya diperankan oleh individu dan atau kelompok masyarakat dalam kehidupan mereka sehari-hari. Pengan Tuhan, dan hubungan manusia dengan ligkungan hidup. Ketiga sisi hubungan tersebut saling terkait dan melangkapi sehingga membentuk sebuah siklus kehidupan yang kamil.

Dalam karya sastra, nilai etis merupakan salah satu nilai yang sangat lazim ditemukan. Hal ini disebabkan karya sastra sering disebut sebagai wahana representasi nilai-nilai kehidupan, yang termasuk dalam filsafat kehidupan. Sementara itu, etika sebagai suatu ilmu yang berbicara mengenai tujuan dan kaidah-kaidah kehidupan dapat juga disebut filsafat kehidupan (Bagus, 2002: 254). Nilai etis dapat dibagi menjadi dua, yakni nilai etis pribadi dan sosial.

Nilai etis pribadi merupakan nilai yang melekat pada pribadi atau individu, baik sebagai mahluk pribadi maupun sebagai mahluk sosial. Artinya, tanpa kehadiran dirinya dalam sebuah situasi sosial, ia tetap berprilaku baik dan benar sesuai dengan norma yang dianut. Karena itu, nilai multikultural etis pribadi berkenaan dengan hal-hal yang sangat pribadi, yang meliputi antara lain: (1) kesedihan, (2) kesetiaan, (3) empati, (4) karakter, dan (5) tahu diri.

Nilai etis sosial merupakan nilai yang mengikat seseorang individu sebagai mahluk sosial. Dalam konteks sosial, nilai-nilai pribadi lebur dan menjadi setingkat di bawah nilai-nilai kemasyarakatan. Nilai multikultural etis sosial meliputi antara lain: (1) hubungan antara rakyat dengan penguasa, (2) keterpinggiran, (3) kesombongan, (4) ketidakpedulian, (5) kebiasaan, (6) kepedulian, perilaku terpuji, dan (7) kesenjangan.

Pendekatan yang dipakai untuk menyingkap makna atau nilai yang terkandung dalam puisi HD adalah pendekatan hermeneutika. Hermeneutika yang dimaksud adalah hermeneutika Ricoeur. Menurut Ricoeur, hermeneutika adalah teori mengenai aturan-aturan penafsiran terhadap teks tertentu atau pun sekumpulan tanda maupun simbol yang dianggap sebagai teks (Suratno, 2005:105). Dengan demikian, hermeneutika berupaya untuk menghilangkan misteri yang terdapat pada simbol atau teks dengan cara membuka selubung yang belum diketahui dan tersembunyi dalam simbol atau teks tersebut.

Ricoeur (2006) mengatakan bahwa sebuah teks adalah otonom dan tidak bergantung pada maksud pengarangnya (pembaca dapat menginterpretasi sendiri). Hermeneutika Ricoeur membutuhkan satu dugaan dan yang satu memperkirakan yang lainnya. Hal itu berarti bahwa teks mengandung pluralitas makna yang inhern yang memungkinkan ditafsirkan dengan berbagai macam cara. Interpretasi terhadap teks merupakan proses yang terbuka, tetapi tidak berarti sewenang-wenang dan berubah-ubah. Dalam melakukan penafsiran yang mendalam, penafsir memasuki dunia teks, mengikuti gerak pemahaman ke makna lain (referensial), dari struktur internal ke dunia yang diproyeksikan (Rafiek, 2010: 6).

Langkah kerja hermeneutika Ricoeur adalah sebagai berikut: (1) langkah simbolik atau pemahaman dari simbol ke simbol, (2) langkah pemberian makna oleh simbol serta penggalian yang cermat atas makna, (3) langkah yang benar-benar filosofis, yaitu berpikir dengan menggunakan simbol sebagai titik tolaknya. Ketiga langkah tersebut berhubungan erat dengan langkah-langkah pemahaman bahasa, yaitu semantik, refleksif, serta eksistensial atau ontologis (Sumaryono , 1999: 111). Ketiga langkah tersebut digunakan dalam merekupasi (mengungkap) nilai etis sosial. Nilai etis sosial yang dibahas hanya nilai etis kepedulian dan saling menolong (perilaku terpuji).

\section{NILAI ETIS KEPEDULIAN}

Dalam cerita yang berjudul La Sirimbone yang Beruntung ditemukan bagian cerita yang

menunjukkan adanya nilai etis yang bernuansa kepedulian, seperti berikut ini.

Hei, siapakah kau anak manusia? Bagaimana kau bisa berada di sini? Tanya Raksasa dengan heran. Dengan takut, La Sirimbone menceritakan asal-asulnya kepada Raksasa itu. Setelah Raksasa itu mendengar cerita La Sirimbone, rupanya sang Raksasa merasa kasihan terhadap nasib si La Sirimbone sehingga sang Raksasa mengizinkan La Sirimbone untuk tinggal di rumahnya. Ia 
(Raksasa) berpesan, kau boleh tinggal di rumah, tapi harus berhati-hati karena di sini banyak binatang buas dan jin yang dapat mencelakaimu karena itu kau sebaiknya tinggal dalam rumah saja.

Pada data di atas, secara semantis dipahami bahwa kata mengizinkan tinggal di rumah dapat diartikan sebagai bentuk kepedulian sang Raksasa kepada La Sirimbone. Selain kelompok kata tersebut ditemukan pula kata yang merujuk pada kata kepedulian, yaitu kata berhati-hati karena di sisni banyak binatang buas dan jin yang dapat mencelakaimu. Kata mengizinkan berasal dari kata izin, yang dapat dimaknai: membolehkan, mengabulkan, tidak melarang, sedangkan kata berhati-hati dapat dimaknai sebagai ungkapan mengingat-ingatkan akan suatu hal.

Berdasarkan pemahaman semantik tersebut, maka dapat ditarik pemahaman secara refleksif bahwa kata mengizinkan yang diikuti dengan kata tinggal di rumah menunjukkan dan atau mempertegas nilai kepedulian sang Raksasa kepada La Sirimbone. Sang Raksasa yang dimaksud dalam cerita ini adalah seorang perempuan yang tinggi besar. Dia adalah penghuni hutan belantara, tempat La Sirimbone dibuang oleh Ibunya karena atas desakan suami keduanya, yang bernama La Patamba. Dengan kata lain, La Patamba adalah Ayah tiri dari La Sirimbone.

Kata yang lain yang menunjukkan kepedulian adalah kata berhati-hati. Biasanya orang yang mengucapkan kata berhati-hatilah adalah yang memilki kedekatan, perhatian dan kasih sayang kepada orang yang disapanya. Apalagi, kalau pernyataannya seperti berikut: berhati-hati karena di sini banyak binatang buas dan jin yang dapat mencelakaimu karena itu kau sebaiknya tinggal dalam rumah saja. Bagian terakhir pemyataan ini, yaitu kau sebaiknya tinggal dalam rumah saja adalah suatu penekanan yang sangat dalam tentang nilai kepedulian sang Raksasa kepada La Sirimbone.

Dari pemahaman semantik dan refleksif tersebut, maka dapat ditarik pemahaman eksistensial bahwa cerita yang berjudul "La Sirimbone yang Beruntung" merupakan cerita (sastra) yang berisikan mengenai nilai kepedulian. Nilai kepedulian merupakan salah satu nilai karakter yang perlu ditumbuh kembangkan di tengah kehidupan masyarakat yang serba individual, cuek terhadap persoalan yang dialami orang lain, masalahku bukan masalahmu dan masalahmu bukan masalabku, dalam bahasa Bugis disebut to pettu perru (orang yang tidak memiliki rasa kepedulian).

Apa yang diucapkan oleh si Raksasa, berhati-hati karena di sini banyak binatang buas dan jin yang dapat mencelakaimu karena itu kau sebaiknya tinggal dalam rumah saja merupakan bentuk ucapan yang penuh perhatian, yang perlu dilestarikan sebagai manusia yang memiliki harkat dan martabat yang tinggi. Nilai yang seperti itu perlu dibumikan di mana dan kapan pun, seperti si Raksasa yang tinggal di tengah hutan. Kata hutan dalam cerita ini dapat dipahami sebagai kesederhanaan: pola hidup dan pergaulan. Kesederhanaan bagi si Raksasa (perempuan yang besar), tetapi memiliki nilai kepedulian terhadap sesama bila dibandingkan La Patamba. La Patamba sebagai pedagang dapat dipahami sebagai kemewahan: pola hidup dan pergaulan, tetapi prilakunya sangat buruk. Contohnya, setelah La Patamba menikahi ibunya La Sirimbone, maka La Sirimbone diusir oleh La Patamba dari rumah.

Jadi, La Patamba seagai representasi kemewahan pola hidup dan pergaulan, sedangkan si Raksasa dan La Sirimbone sebagai representasi kesederhanaan pola hidup dan pergaulan. Namun, ketika dihubungkan dengan soal nilai maka kemewahan pola hidup dan pergaulan belum tentu lebih bernilai dari sisi etisnya dibandingkan dengan kesederhanaan pola hidup dan pergaulan. Nilai seseorang bergantung pada perbuatan baik yang dilakukannya. Dalam Q.S. (Al-Baqarah: $22 \Downarrow$ ) yang artinya, "Sesungguhnya budak yang mukmin lebih baik daripada orang musyrik, walaupun dia menarik hatimu."

\section{SALING MENOLONG ATAU PERILAKU TERPUJI}

Suatu cerita masalah lalu yang dianggap menarik dan sangat baik untuk dijadikan sebagai teladan dalam hidup dan kehidupan manusia di era kini karena di dalamnya dianggap mengandung nilai saling menolong (perilaku terpuji). Cerita yang dimaksud adalah cerita antara semut dengan merpati, seperti berikut ini.

"Tolong, aku terjatuh ke sungai. Tolong aku..." teriak Semut.

"Aku akan menggunakan potongan ranting ini untuk menolong Semut" guman Merpati.

"Beribu-ribu terima kasih aku ucapkan kepadamu Merpati karena telah menyelamatkan nyawaku" ucap Semut.

"Tolong, aku terperangkap. Tolong...Tolong" teriak burung.

"Lihat, ada seekor burung yang terperangkap di jaring itu" ucap Semut.

"Ayo teman-teman kita tolong burung itu" teriak Semut.

"Terima kasih Semut kamu telah menolongku" ucap Merpati. 
Pada data di atas, secara semantik kata atau kelompok kata “...akan menggunakan potongan ranting ini untuk menolong, Semut" mengandung makna perilaku terpuji. Pemahaman seperti itu didasarkan karena adanya kata menolong. Kata menolong merupakan bentuk turunan dari kata dasar tolong, yang berarti bantu. Dengan demikian, jika kata tolong mendapatkan awalan me- maka menjadi menolong, yang berarti sama dengan membatu. Kata Membantu yang dimaksud dalam konteks di atas tentunya mengarah kepada sesuatu yang dianggap baik dan sangat bermanfaat. Hal tersebut dapat diselisik dari rangkaian kata yang tersusun sebelum kata menolong, yaitu: akan, menggunakan, potongan, ranting ini, untuk. Walaupun kata membantu dapat saja berarti sebaliknya, yakni perbuatan jahat dan sangat destruktif. Itulah sebabnya dalam kutipan tersebut digunakan kata menolong bukan kata membantu.

Dari pemahaman semantik tersebut, maka secara reflektif dapat dipahami bahwa pemakaian kata menolong ternyata tidak selalu dapat beriringan atau saling menggantikan dengan kata membantu karena kata membantu memiliki dua persepsi makna, yakni dapat berarti baik dan sangat bermanfaat dalam proses hubungan antara yang satu dengan yang lainnya dan sebaliknya dapat pula berarti sesuatu yang bersifat jahat dan sangat destruktif dalam kehidupan, seperti membantu orang untuk melakukan perbuatan yang merugikan pihak lain. Berbeda halnya dengan kata menolong, kata menolong hanya dipersepsi dengan satu makna, yakni sesuatu yang bersifat positif (baik dan sangat bermanfaat) dalam kehidupan kemasyarakatan.

Pada data tersebut ditemukan kata semut dan merpati. Semut dan merpati adalah dua jenis binatang yang sangat berbeda dari segi struktur bentuk fisiknya, tetapi di sisi yang lain mereka memiliki kesamaan kejiwaan untuk melakukan sesuatu yang baik dan sangat bermanfaat dalam kehidupan, yang disebut perilaku terpuji atau kata lainnya adalah saling menolong secara ikhlas. Yang empunya cerita tentunya memiliki pertimbangan yang matang dalam memilih semut dan merpati sebagai tokoh yang menggerakkan ceritanya. Pertimbangan itu dapat dipersepsi sesuai dengan sudut pandang dan pemahaman pembacanya. Oleh karena itu, pertimbangan yang diberikan di sini dapat saja berbeda dengan pertimbangan pembaca lainnya. Hal tersebut sesuai dengan prinsip sastra, termasuk cerita rakyat yang selalu memberi ruang terbuka untuk diinterpretasi oleh para penikmat.

Interpretasi yang diberikan di sini, mengapa yang empunya cerita memilih tokoh semut? Semut adalah hewan kecil yang tergolong serangga. Meskipun kecil, semut memiliki prinsip hidup yang dapat dijadikan sebagai teladan dalam kehidupan bermasyarakat. Misalnya, semut memiliki semangat yang besar dan tidak pernah putus asa sehingga mereka tidak pernah merasa kecewa ketika usahanya belum berhasil; semut memiliki sifat rajin dan ulet dalam bekerja; semut senantiasa menjaga nilai-nilai kegotongroyongan. Hal ini dapat kita cermati ketika ada salah satu kawannya mendapatkan makanan maka dengan cepat kawannya yang lain datang membantu untuk mengangkat atau membawa makanan tersebut ke sarangnya; semut memiliki sifat sabar, tetapi manakalah diinjak-diinjak maka mereka akan melawan, meskipun mereka akan hancur. Itu berarti semut bukanlah hewan pengecut.

Semut juga memiliki sifat yang terpuji dan selalu mengingat jasa baik siapa saja yang pernah menolongnya, seperti dalam kutipan berikut:

"Tolong, aku terperangkap. Tolong... Tolong" teriak burung.

"Lihat, ada seekor burung yang terperangkap di jaring itu" ucap Semut.

"Ayo teman-teman kita tolong burung itu" teriak Semut.

"Terima kasih Semut kamu telah menolongku" ucap Merpati.

"Iya, sama-sama merpati. Kamu juga pernah menolongku ketika terjatuh dan terbawa arus sungai."

Merpati adalah burung yang memiliki kedekatan secara khusus dengan manusia. Karena dekatnya, manusia sering membuatkan kandang merpati di sekitar rumahnya. Manusia sering membeli makanan untuk merpati-merpati yang terbang di sekitarnya. Merpati tidak pernah ingkar janji terhadap pasangannya. Sekali ia menjatuhkan cintanya maka cinta itu tidak pernah berpindah ke lain hati. Jika salah satu di antara mereka telah mati, sisa hidup yang ditinggal akan diselimuti kesedihan, kemurangan, dan kesepian sampai ia menyusul pasangannya yang telah mati sebelumnya. Itulah sebabnya orang sering berkata merpati tak pernah ingkar janji.

Merpati, selain dijadikan icon burung yang tak pernah ingkar janji, rupanya merpati juga masih memiliki sifat terpuji lainnya. Misalnya, merpati memiliki sifat yang rajin, subuh hari sebelum manusia bangun mereka telah bangun terlebih dahulu; merpati senantiasa memelihara nilai gotong royong, ketika merpati betina membuat sarang maka merpati jantan membantu menyiapkan kebutuhan untuk pembuatan sarang, ketika merpati betina mengerami telurnya maka merpati jantan siap pula mengganti merpati betina untuk mengeram. Mereka saling membantu satu sama lain dalam menjalani kehidupannya. Mereka tidak 
pernah saling menyerang, tidak pernah saling merebut, tidak pernah merasa iri dan apalagi dengki terhadap kebahagian yang dialami oleh merpati lainnya.

Dari pemahaman semantik dan refleksif tersebut, maka dipahami pemahaman eksistensial bahwa pemilihan tokoh semut dan merpati dalam cerita oleh yang empunya cerita sangat beralasan karena kedua hewan itu memang sangat pantas untuk dijadikan teladan dalam hidup dan kehidupan masyarakat, khususnya di era globalisasi seperti sekarang ini. Di era globalisasi terdapat gejala kehidupan serba individual, serba material, dan serba permisif. Gejala-gejala tersebut tidak sesuai dengan prinsip-prinsip kemanusiaan dan atau apalagi norma-norma adat ketimuran, yang selama ini menjunjung tinggi nilai kebersamaan, kegotongroyongan, dan menghargai adat tata kelakuan sebagai sumber pedoman dalam pergaulan dalam masyarakat.

Semut sebagai hewan yang kecil mampu mengangkat dan membawa benda (makanan) yang lebih besar daripada ukuran badannya ke sarangnya karena dilakukan dengan cara gotong royong. Demikian pula burung merpati, ketika burung merpati betina akan membuat sarang untuk menyambut masa bertelur dan tempat berlindung bagi anak-anaknya yang akan lahir maka merpati jantan turun tangan mencari ranting. ranting kayu atau alang-alang agar sarang yang akan dibuat cepat diselesaikan. Bahkan, merpati jantan siap membantu merpati betina untuk mengerami telur yang akan menetas.

Bentuk gotong royong yang diperankan oleh kedua mahluk kecil tersebut sangat indah untuk diterapkan atau diperankan dalam kehidupan kapan dan di mana pun karena menyentuh nilai-nilai harkat kemanusiaan yang harus selalu dijaga dengan baik, itulah gotong royong. Gotong royong adalah kerja bersama, berusaha bersama, berbagi bersama, dan menikmati bersama merupakan sendi kehidupan masyarakat ketimuran (Indonesia). Indonesia terlahir dari gotong royong, bahu-membahu mengangkat harkat dan martabat bangsa sejak zaman sebelum merdeka sampai dengan saat mengisi kemerdekaan, seperti yang kita rasakan sekarang ini. Pemerintah, mulai dari tingkat desa sampai dengan tingkat nasional atau presiden tidak hentinya-hentinya mengimbau atau mengajak semua elemen bangsa tanpa melihat latar belakang suku, agama, dan ras untuk bekerja bersama memajukan bangsa ini agar setaraf dengan bangsa-bangsa lain yang sudah lebih maju daripada bangsa kita.

Nilai gotong royong yang tersirat dalam cerita rakyat perlu digali secara terus-menerus kemudian disebarkan kepada para generasi muda agar mereka tahu bahwa nenek moyong kita dapat mewariskan bangsa ini kepada kita karena terjalinnya nilai-nilai gotong royong di antara mereka. Pada prinsipnya, gotong royong merupakan suatu sikap yang sangat positif karena pekerjaan yang sulit dapat menjadi mudah dan pekerjaan yang berat dapat menjadi ringan, seperti apa yang dicontohkan oleh semut di atas bahwa dapat mengangkat benda yang lebih besar daripada badannya karena gotong royong.

Berkaitan dengan istilah gotong royong, dalam kearifan lokal Bugis dikenal istilah rebbah si patokkong, mali' si parappe, dan malilu si pakainge (rebah saling mendirikan/membangunkan, hanyut saling menahan, keliru saling mengingatkan). Yang maknanya dapat dipahami bahwa kehidupan bahagia adalah kehidupan yang di dalamnya terdapat nilai gotong royong atau tolong-menolong. Kesuksesan tidak dapat dicapai tanpa melibatkan pihak lain. Hal ini sejalan dengan apa yang terdapat di dalam al-Quran dan Hadits bahwa kita hendaknya harus saling menolong dalam kebaikan demi mendapatkan rasa kebahagian. "Dan orang-orang yang beriman, lelaki dan perempuan, sebagian mereka (adalah) menjadi penolong bagi sebagian yang lain. Mereka menyuruh (mengerjakan) yang ma'ruf, mencegah dari yang mungkar, mendirikan shalat, menunaikan zakat, dan mereka táat kepada Allah dan Rasul-Nya. Mereka itu akan diberi rahmat oleh Allah Subhānahu wa Ta'ālā.: sesungguhnya Allah Maha Perkasa lagi Maha Bijaksana".

Dalam surat (al-Maidah ayat 2) Allah menyatakan:

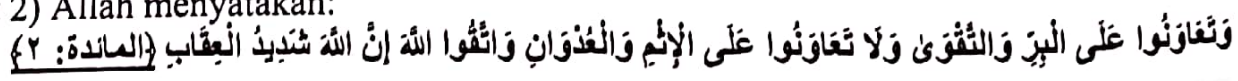

Artinya: Dan tolong-menolonglah kamu dalam (mengerjakan) kebaikan dan takwa, dan jangan tolongmenolong dalam berbuat dosa dan pelanggaran. Dan bertakwalah kamu kepada Allah, sesungguhnya Allah amat berat siksa-Nya.

Tolong-menolong (taawun) merupakan hal yang esensial dalam kehidupan masyarakat karena sebagai mahluk individu dan sekaligus sebagai mahluk sosial. Manusia sebagai mahluk sosial tidak dapat berkembang dan apalagi megalami kemajuan tanpa bantuan pihak lain karena sangat lemah dan sangat tidak sempurna. Dalam hadits Muttafaq Alaih dinyatakan bahwa, "Seorang mukmin terhadap mukmin lainnya seumpama bangunan saling mengokohkan satu dengan yang lain. (Kemudian Rasulullah SAW merapatkan jari-jari tangan beliau)". http://pendidikanmendows.blogspot.co.id/2016/06/hadits-tentang-tolongmenolong.html 17-08-2017. 
SIMPULAN

Cerita rakyat perlu digali secara terus-menerus kemudian disebarkan kepada para generasi muda agar mereka tahu bahwa nenek moyong kita dapat mewariskan bangsa ini kepada kita karena adanya nilai-nilai kepedualian antara sesama, baik antara manusia dengan manusia, manusia dengan alam lingkungannya, dan manusia dengan Sang Penciptanya. Di samping itu, terjalinnya nilai-nilai gotong royong di antara anak bangsa. Pada prinsipnya, gotong royong merupakan suatu sikap yang sangat positif karena pekerjaan yang sulit dapat menjadi mudah dan pekerjaan yang berat dapat menjadi ringan, seperti apa yang dicontohkan oleh semut di atas bahwa dapat mengangkat benda yang lebih besar daripada badannya karena gotong royong.

\section{DAFTAR PUSTAKA}

Al-Qarni, A. 2008. La Tahzan (Jangan Bersedih). Terjemahan Samson Rahman. Jakarta: Qisthi Press.

Cerita Rakyat Nusantara. 2016. Cerita Semut dan Merpati. (http://www. Kumpulan dongeng anak.com dongeng- fabel-semut-dan-merpati.html), diakses 30 Juli 2017

2015. Cerita La Sirimbone. (http://dongengceritarakyat.com/cerita-rakyat-sulawesi-tenggarakisah-la-sirimbone/), diakses 30 Juli 2017

Gazalba, S. 1989. Sistematika Filsafat III. Jakarta: Bulan Bintang.

Iskandar, T. 1989. Kamus Dewan. Kuala Lumpur: Dewan Bahasa dan Pustaka.

Muliadi. 2014. Nilai Multikultural Teks Puisi Husni Djamaluddin dalam Kajian Hermeneutika. Disertasi tidak diterbitkan. Malang: PPs UM Malang.

Mulyana, R. 2004. Mengartikulasikan Pendidikan Nilai. Bandung: Alfabeta.

Palmer, R.E. Hermeneutika: Teori Baru Mengenai Interpretasi. Terj. Masnur Hery dan Damanhuri Muhammad. 2003. Yogyakarta: Pustaka Pelajar.

Rafiek, M. 2010. Teori Sastra: Kajian Teori dan Praktik. Bandung: Refika Aditama.

Ricouer, P. 1981. Hermeneutika Ilmu Sosial. Terjemahan Muhammad Syukri. 2006. Yogyakarta: Kreasi Wacana.

2006. Filsafat Wacana. Terj. Masnur Hery. Yogyakarta: IRCiSod.

Sumaryono, E. 1999. Hermeneutika: Sebuah Metode Filsafat. Yogyakarta: Kanisius. Suratno. 2005. Pluralisme Agama dalam Hermeneutika Paul Ricoeur. Jurnal Universitas Paramadina, 4(1):
105-110. 
